\title{
Suburban Residents' Preferences for Livable Residential Area in Finland
}

\author{
Markku Karjalainen (D), Hüseyin Emre Ilgın *, Lauri Metsäranta and Markku Norvasuo (D) \\ School of Architecture, Faculty of Built Environment, Tampere University, P.O. Box 600, \\ FI-33014 Tampere, Finland; markku.karjalainen@tuni.fi (M.K.); lauri.metsaranta@tuni.fi (L.M.); \\ markku.norvasuo@tuni.fi (M.N.) \\ * Correspondence: emre.ilgin@tuni.fi
}

check for updates

Citation: Karjalainen, M.; Ilgın, H.E.; Metsäranta, L.; Norvasuo, M. Suburban Residents' Preferences for Livable Residential Area in Finland. Sustainability 2021, 13, 11841 https://doi.org/10.3390/su132111841

Academic Editor: Miguel Amado

Received: 29 September 2021

Accepted: 25 October 2021

Published: 26 October 2021

Publisher's Note: MDPI stays neutral with regard to jurisdictional claims in published maps and institutional affiliations.

Copyright: (C) 2021 by the authors. Licensee MDPI, Basel, Switzerland. This article is an open access article distributed under the terms and conditions of the Creative Commons Attribution (CC BY) license (https:// creativecommons.org/licenses/by/ $4.0 /)$.

\begin{abstract}
This paper analyzed Finnish suburban residents' preferences (including their perception of wood as a building material) for livable residential areas through a survey questionnaire. The 243 responses received highlighted the following: residents were generally satisfied with the general condition of their residence; the majority supported life in one- to two-story buildings and a low-density residential environment; living in the center was found more attractive by most; the most popular facade material was wood; considerations regarding the immediate environment, e.g., proximity to nature and child-friendly areas in the immediate vicinity, were evaluated as important parameters; participants' attitudes towards the use of wood in construction were generally very positive; residents generally considered wooden buildings more beautiful, more environmentally friendly/ecological, and as having a healthier indoor climate than buildings made of non-wood materials; and fire safety and cost-competitiveness were issues of skepticism. It is believed that this study will provide insights to key stakeholders, e.g., architects, developers, policymakers, to better meet the needs of suburban apartment-dwellers.
\end{abstract}

Keywords: suburban residents; participative process; livable; residential area; wood/timber; Finland

\section{Introduction}

Finnish suburban housing estates (lähiö) (Figure 1) are reinforced concrete-framed buildings that were constructed mostly in the 1960s and 1970s to accommodate large-scale migration from rural areas to cities, with a long history as symbols of urban rootlessness, social issues, and the failed integration of immigrants [1,2]. Due to these projects, overcrowding in the central city was alleviated, although large Finnish cities continued to attract rural migrants. For example, from the early 1960s to late 1980, the population of central Helsinki fell by about 40 percent, while the population of Helsinki suburbs increased by more than 65 percent [3]. Additionally, in the mid-1960s, a major paradigm shift occurred in suburban planning, and forest suburbs close to nature gave way to a compact city model in a square block and street layout [4]. Today, more than one million Finns, a fifth of the total population, live in these hundreds of suburban properties [5].

Since the peak of their construction in Finland in the 1970s, Finnish suburbs have often been seen in a negative light and have had a worse reputation than any other residential area in Finland [6,7], much like in other similar areas in Western Europe [8-10]. Moreover, such areas began to be perceived negatively shortly after they were built [11,12]. In addition to the identified social problems [13], Finland's suburban apartments have also faced fundamental technical problems, such as poor technical conditions, low energy efficiency, lack of balconies, and unpleasant appearance [14].

There are many projects and programs supported by the Finnish government $[15,16]$ to eliminate the above-mentioned problems and provide comprehensive development for suburban areas in Finland, such as The City of Helsinki's Suburb Programme [17]. The main aim of these programs is to provide positive, long-term development that facilitates 
the well-being of residents, the vitality of spaces, and the functionality and attractiveness of the residential environment for all types of residents.

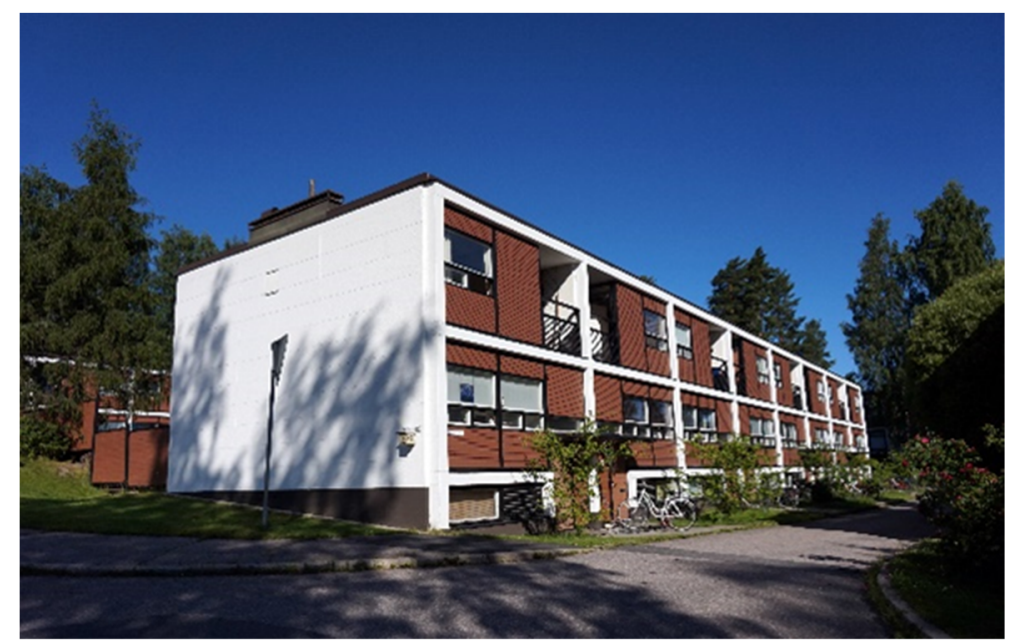

Figure 1. A suburban residential building in Finland built in the 1960s (source: Wikipedia/Tiia Monto).

At this point, identifying people's preferences and expectations plays a critical role in realizing these projects and thus developing user-oriented sustainable strategies $[18,19]$. However, in housing studies, understanding of the perceptions and preferences of multiple actors, including residents, is often lacking [20-23]. Although issues related to (livable) suburban housing have been on the agenda for a long time in Finland, there is little researchbased understanding of such areas and their development over the past few decades [24]. Among these studies, in the Finnish context, Karjalainen [25,26], while examining suburban residents' attitudes towards multi-storey wooden apartments, presented some important results of residents' preferences, such as current residence and type of building to be moved into-see Section 4.

Furthermore, worth mentioning here, although livability is a popular term used to express the quality of urban environments considering the needs and expectations/preferences or residents' satisfaction with living in a city/suburb [27], there is no consensus on how to describe livability and its main elements [28-31]. Based on comprehensive literature reviews (e.g., [28,30,32]), the most common definitions seem to share natural and built elements, and refer to how these connect to individuals. On the other hand, residential preferences are made up of a complex set of factors, such as price level, size, duration of use, accessibility to amenities such as nature and transportation, as well as social interaction with friends and family [33]. In addition, since these preferences may be different for each individual and may change over time, it is believed that making comparisons in similar contexts in the same country or region will yield more consistent and accurate results (e.g., [34]).

As the model of livable Nordic countries is based on the values of environment, equality, openness, and efficiency, the initiative should contribute to the dissemination of Scandinavian approaches to good and sustainable urban development worldwide [35]. In this sense, Scandinavian sustainable cities directly link to the United Nations' Sustainable Development Goals [36], including making cities inclusive, safe, resilient, and sustainable; ensuring healthy lives and promoting well-being; guaranteeing access to water and sanitation; and taking urgent action to combat climate change and its effects. In addition, among the Nordic countries, in terms of a livable residential environments, Finland takes the lead in some issues, such as taking proximity to the forest as an important design input when planning housing development or declaring broadband access in residential areas as a legal right for every citizen, within the scope of implementing intelligent technologies in the smart city concept [37].

In the literature, there have been several studies of urban livability and housing preferences in the last decade (e.g., [27,31,33,38-48]), but suburban residents' preferences 
for livable residential areas (including the role of the use of wood as a building material in this sense) have not been extensively studied in the Finnish context before. This study aimed to fill this knowledge gap and address, from a multidimensional perspective, Finnish suburban residents' preferences for a livable housing environment and its relationship to the use of wood as a building material.

It is worth mentioning here that as a large-scale public project managed by the Finnish Ministry of Agriculture and Forestry, the possibilities for using wood have been expanded to include repairs and expansions of suburban concrete buildings [16]. The abovementioned dimensions include the main factors behind residential satisfaction with the current residence, willingness to move, preferred number of floors, preferred density and location of the building on the plot, preferred facade material, preferred features in the residential environment, perception of wood as a building material, perception of the ecological features of the use of wood, and finally, feedback to the developers and wooden apartment designers.

Overall, this research aimed to provide a representative analysis of Finnish suburban residents' preferences for a livable residential environment and its relationship to the use of wood as a building material. In doing so, this study sought to identify the main parameters behind the residential satisfaction with the current residence, willingness to move, preferred number of floors, preferred density and location of the building on the plot, preferred facade material, preferred features in the residential environment, perception of wood as a building material, and perception of the ecological features of the use of wood.

From the point of view of Finland's urban and housing policy, suburban housing estates seem to pose a significant challenge in the coming years [24]. It is believed that the results will provide insights for many public and private stakeholders to renovate and design suburban apartments, to better meet the needs of various types of residents, and to enhance the attractiveness of these buildings in Finland, as well as other countries.

The remainder of this research is organized as follows: First, an explanation of the research method used in the study is given. This is followed by the results of the main highlights of the survey questionnaire. In Section 4, the discussion part is provided. Finally, the results are presented.

\section{Research Method}

This research was carried out through a project-based survey questionnaire called "The Wood at Visibility at the Tampere University", which is part of the Growth and Development from Wood Support Program run by the Finnish Ministry of the Environment. The survey (see Appendix A) was conducted with a combination of mail and online survey questionnaires. Responses were handled anonymously, and no personally identifiable data were collected or used during the analysis phase.

The main population of the material was 800 Finnish-speaking people aged 18-69 in the postcode 00720, or the Pukinmäki-Savela area (Figure 2); this area was chosen because it represents a typical Finnish suburban district in terms of building stock and density, and is suitable for suburban development research on this basis. Pukinmäki is a district in the northeastern part of Helsinki. The area was annexed to Helsinki in 1946 and the first few blocks of flats were built in the 1960s. Most of the flats are from the 1970s and 1980s. On the other hand, Savela (Figure 3) is a residential area in the Pukinmäki district. In the 1960s and early 1970s, Savela was threatened by the zoning and detachment of detached house parcels in the city as partly green space. However, over time, the area transformed from a detached area to an apartment area, with mostly low-rise apartments built in the 1980s and 1990s.

The sample, namely, 800 Finnish-speaking people aged 18-69 in the area with the permanent address of the region according to the population information system, was chosen randomly. The survey data largely represented the population of the selected area, but there were also minor differences in representation among background variables such as gender and age. In terms of gender, $54 \%$ and $57 \%$ were female, $46 \%$ and $43 \%$ 
were male in the whole population and sample, respectively. In terms of age groups, the older population was slightly overrepresented, while younger respondents were slightly underrepresented; in the whole population and sample, $20 \%$ and 30\% were aged $60-69$, and $25 \%$ and $15 \%$ were aged $18-29$, respectively. As regards education level, high school and university graduates constituted $73 \%$ of the entire population; this rate was $90 \%$ in the sample group. On the other hand, landlord-ownership was more represented in the sample than those living in rental housing; the ratios of owner-occupied dwellings and flats with tenants in the whole population and sample were $46 \%$ and $52 \%$ (and $2 \%$ other), and $62 \%$ and $38 \%$, respectively.
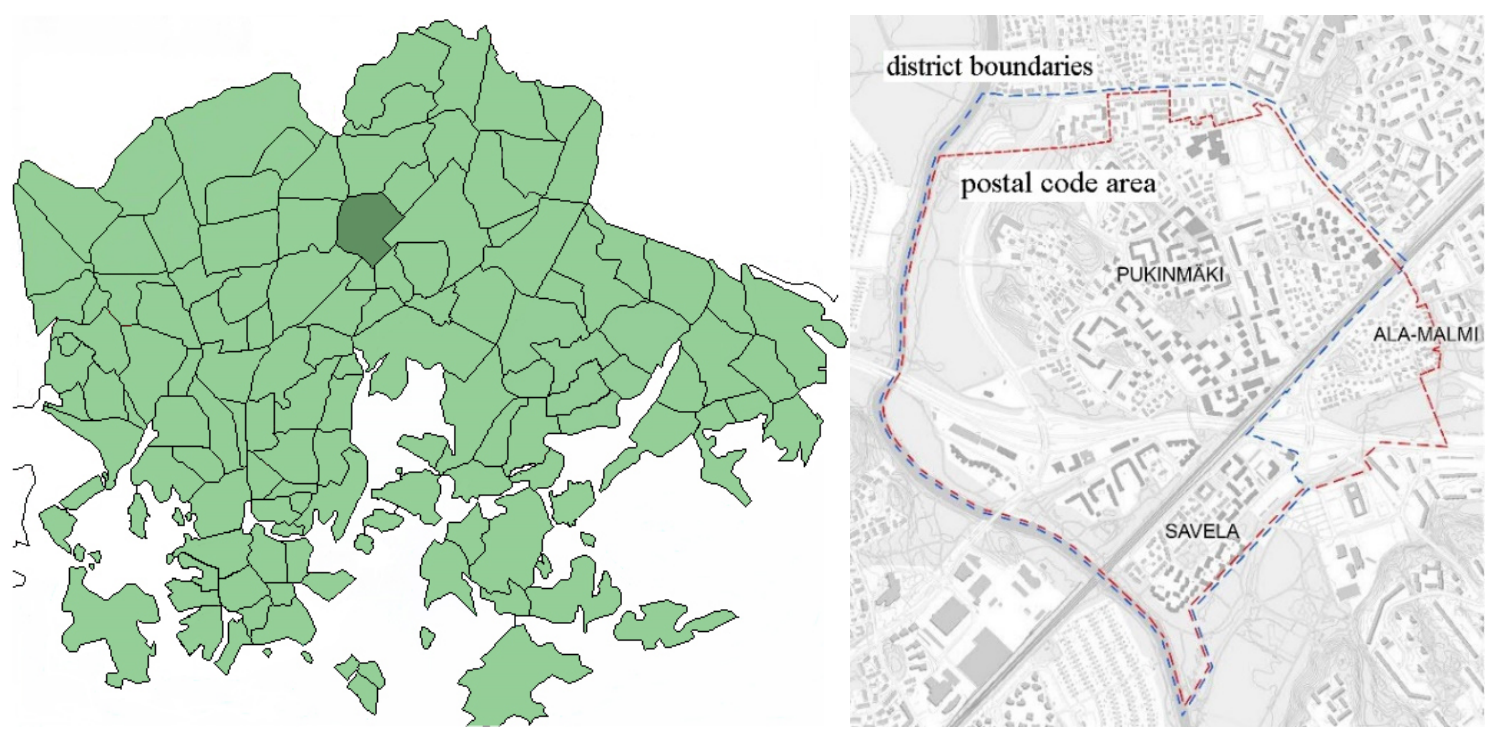

Figure 2. Pukinmäki-Savela area in the City of Helsinki (Finland).

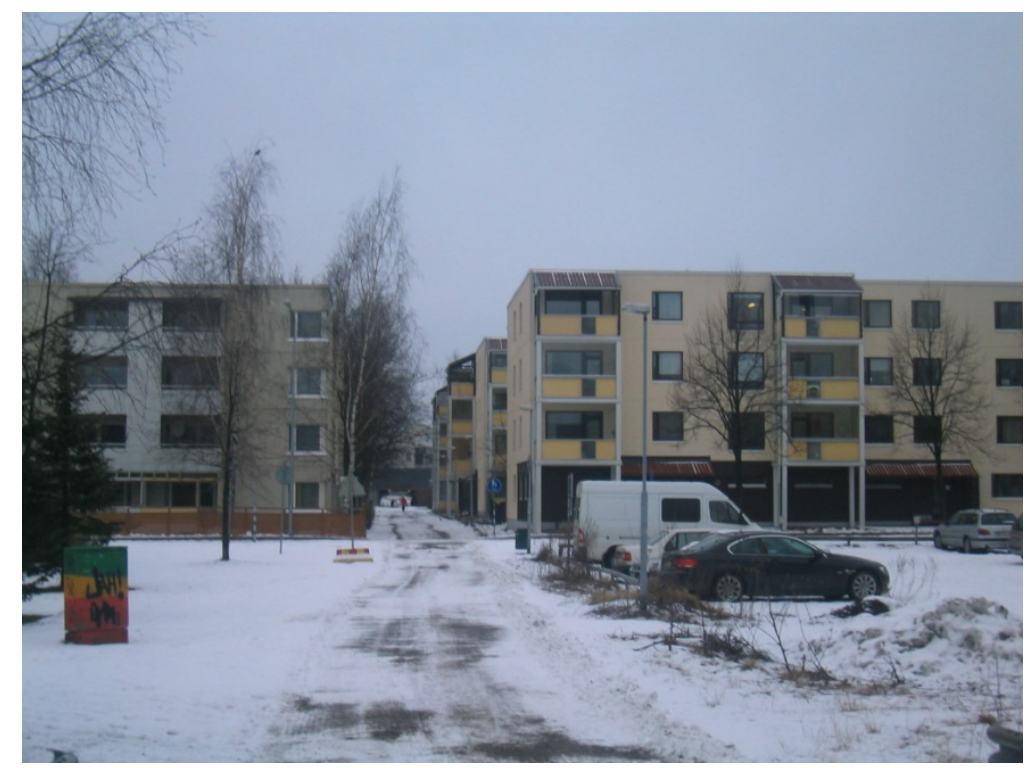

Figure 3. Savela area.

Online surveys started on 18 May 2020. The first response came on 25 May; accordingly, it can be assumed that postal forms reached residents on the same day. As regards the forms for the first mail submission, the return date was 1 June, with only a week left for residents to respond. Initially, 149 responses were received to the questionnaire. Responses were distributed with 110 responses on paper forms and 39 responses to an online questionnaire. 
Reminder-round questionnaires were delivered to the post office on June 10. The actual deadline for response was abandoned, and instead, respondents were asked to return a completed questionnaire one week after it arrived. This was to avoid the impact of mail delay on the response time. Paper surveys for the reminder round reached residents on 15 June, based on online survey responses. During the reminder round, 94 new responses arrived, 67 on paper and 27 online. A total of 243 responses were received for the entire survey, corresponding to a response rate of $30 \%$.

The survey concentrating on suburban residents' preferences was divided into 9 parts (Figure 4). In the first part, Part A-residential satisfaction with the current residence, respondents were asked to rate the residential area and the quality and price/rent level of the residence. A Likert-type scale (from 1 (very dissatisfied) to 5 (very satisfied)) was used, along with "I cannot say". In Part B-willingness to move, the surveyed residents were asked whether they planned to move from their current residential area, considering their background information such as age, level of education and family type, with "Yes", "I cannot say", and "No" options. In Part C-preferred number of floors, participants were asked about the floor number limits (e.g., 1-2, 5-6-storey) of the buildings they would prefer in the area they live in, providing "I cannot say" and "It does not matter" options. In this part, the effect of the building type inhabited on the number of floors preference was also assessed. In Part D-preferred density and location of the building on the plot, participants were asked about their preferences regarding the density (e.g., closely, loosely) and location of the building on the plot (e.g., close to the street, in the center) they would like to live in, offering "I cannot say" and "It does not matter" options. In Part E-preferred facade material, residents participating in the survey were asked about their preferences regarding facade material (e.g., wood, brick, stone) of the building they would like to live in. In Part F-preferred features in the residential environment, participants were asked to report their preferences regarding the environmental characteristics (e.g., child-friendliness, closeness to nature) of the area they would live in as free comments. In Part G-perception of wood as a building material, respondents were asked to express their opinions on the statements presented (e.g., its suitability for buildings, its fire safety) about wood as a building material. Here, a Likert-type scale (from 1 (completely disagree) to 5 (completely agree)) was used along with "I cannot say". In Part H-perception of ecological qualities of the use of wood, surveyed residents were asked to comment on the ecological dimension of wood use. A Likert-type scale (from 1 (non-ecological) to 5 (ecological)) was used along with "I cannot say". Finally, in Part, I-feedback, respondents were asked to give feedback to the developers and wooden apartment designers.

\section{Results}

\subsection{Background Information}

In the survey, the participants (57\%) were mostly females. More than $30 \%$ of the respondents were relatively old, i.e., over 60 years old, while more than half $(55 \%)$ of the respondents were between 30 and 60 years old. In terms of education level, most of the residents (55\%) were highly educated or university graduates, while only $10 \%$ were primary school graduates. Regarding household size, almost half (46\%) of the surveyed residential communities contained at least two adult households. About a third (32\%) of respondents were single, and the remaining $22 \%$ were families with children. By type of homeownership, of those surveyed, 62\% lived in owner-occupied dwellings, and 38\% were rented.

\subsection{Residential Satisfaction with the Current Residence}

The surveyed people were generally satisfied with the overall condition of their residence (the total occurrence of "very satisfied" and "satisfied" options) (82\%), with a negligible minority of respondents being dissatisfied ( $2 \%$ ), while "neutral" had a $16 \%$ occurrence-see Figure 5. Among the criteria presented, they were most satisfied with their residential area (90\%), followed by the quality of the residence $(79 \%)$, and price/rental level $(73 \%)$. 


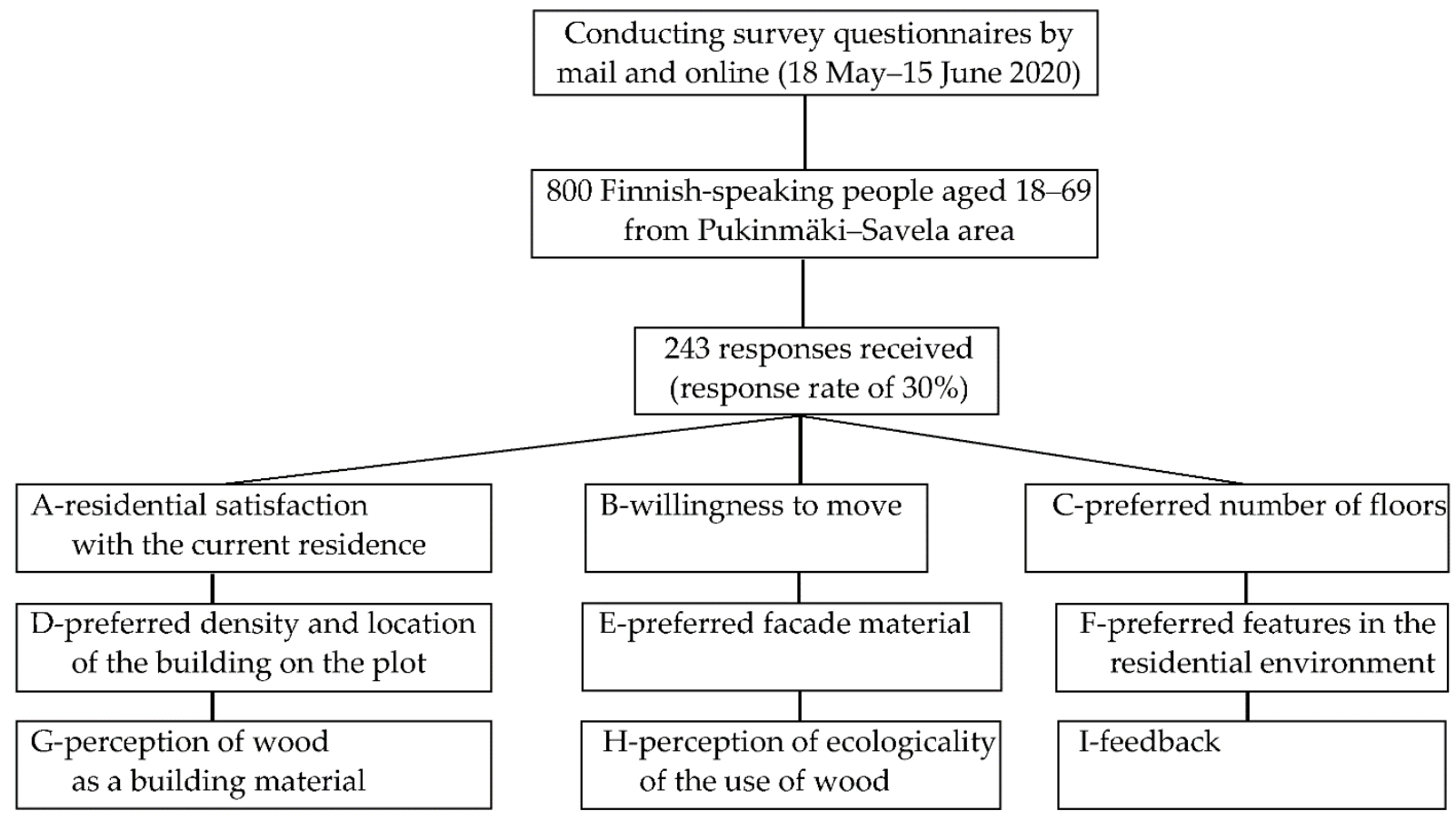

Figure 4. Research methodology.

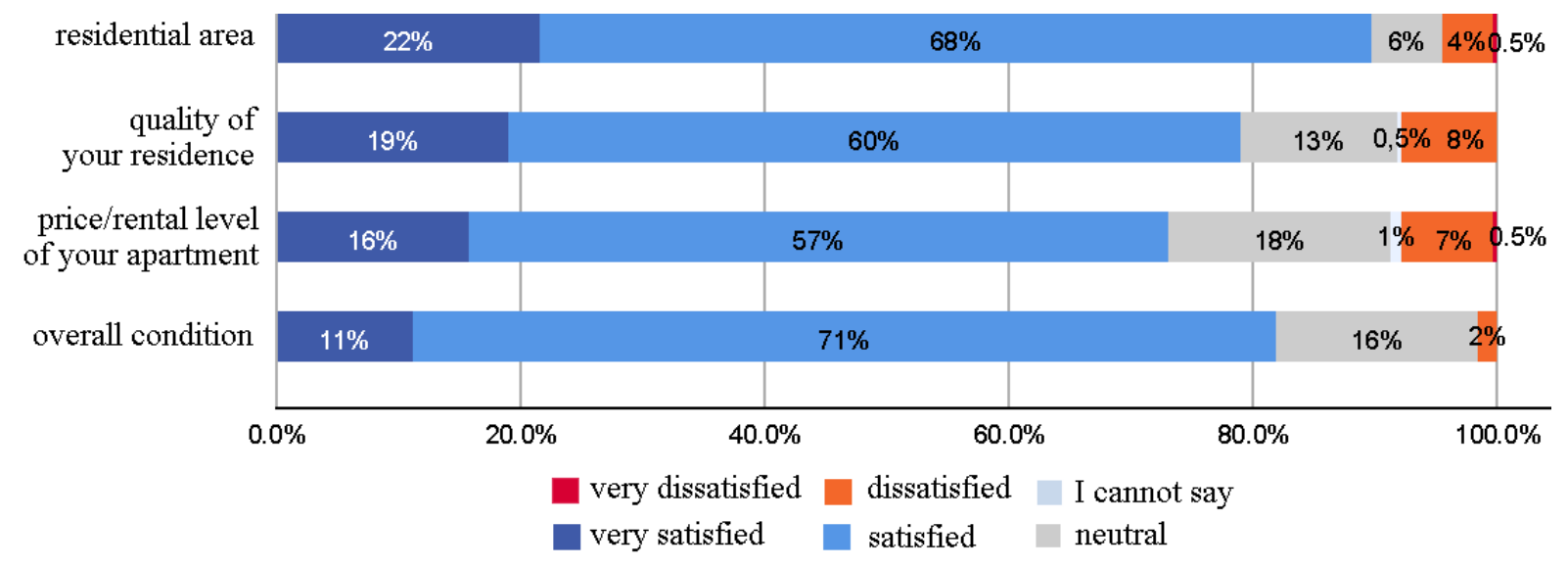

Figure 5. Residents' satisfaction with the current residence.

Additionally, based on the open answers (228 responses) in this part of the survey, the most important parameters influencing current residency decisions are listed below: (1) transportation links (104 mentions/46\%); (2) price and rental level (55 mentions $/ 24 \%$ ); (3) location (46 mentions $/ 20 \%$ ); (4) nature or closeness to nature (38 mentions $/ 17 \%)$; (5) tranquility or comfort of the area (31 mentions/14\%); (6) familiarity of the area (27 mentions/12\%); (7) suitability of apartment or size or floor plan (26 mentions $/ 11 \%)$; (8) family reasons or relatives in the area ( 25 mentions $/ 11 \%)$; and (9) good services nearby (20 mentions/9\%)

\subsection{Willingness to Move}

As seen in Figure 6, less than a third (31\%) of the respondents planned to move from the area, while half (51\%) did not plan to move. Particularly between different age groups, there were differences in participants' willingness to act. Of those under the age of 30, $44 \%$ planned to move and only a quarter did not plan to move from existing residential areas. Moving towards older age groups, the desire to move decreased steadily, and 
only one-fifth of those over 60 planned to move. Long-term residents over the age of 60 were most satisfied with their residential area, with only a fifth of them planning to leave the area.

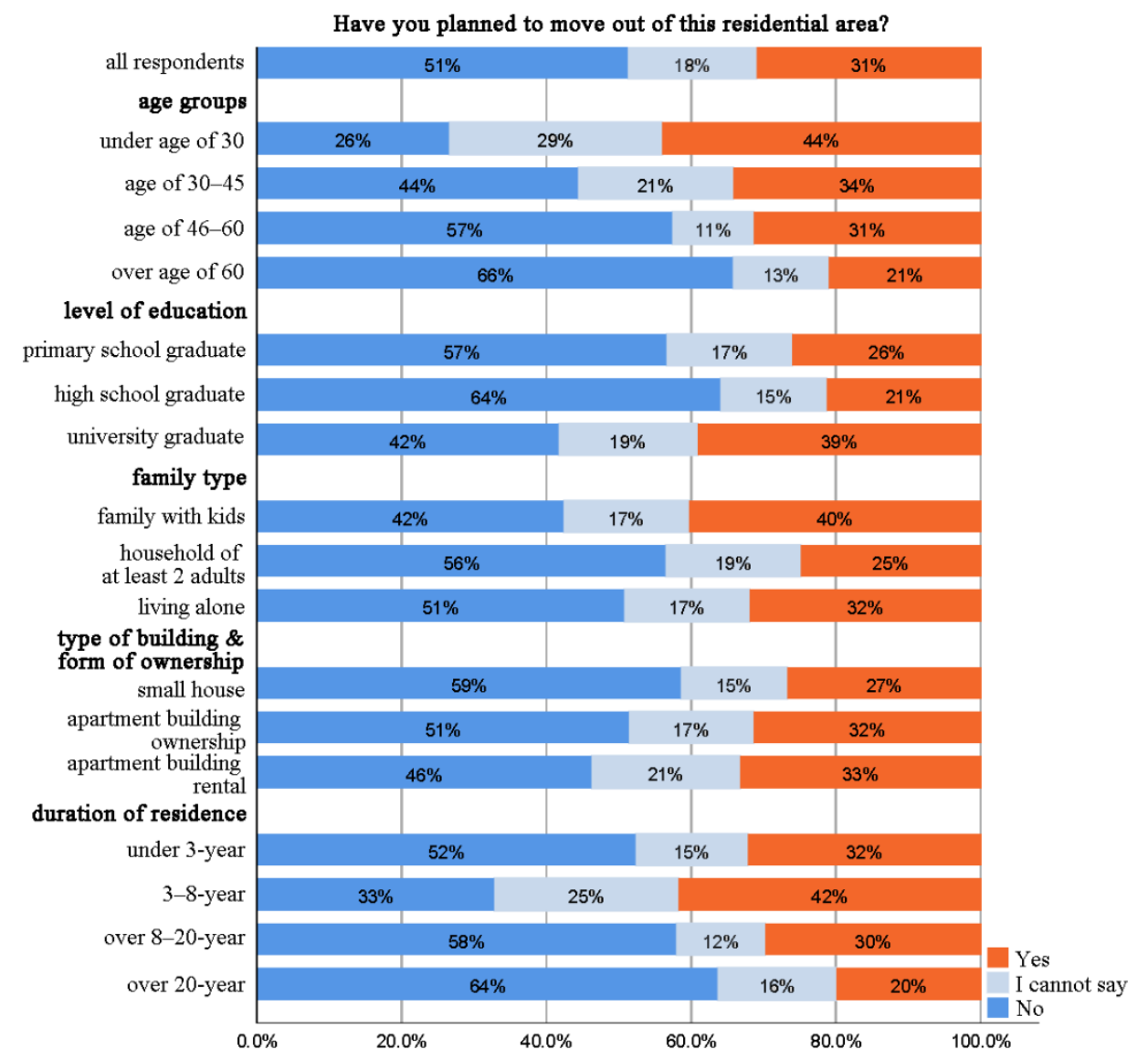

Figure 6. Residents' willingness to move.

Education level and homeownership may explain the willingness to move. University graduates were more willing to leave the area than others. Those who own a detached house or apartment showed a slightly lower reluctance to move than a resident with a rental flat, certainly due to the property owners' greater commitment to the area. Moreover, the changing living conditions of families with children and the change in the need for space may have created a greater desire to move compared to other family types. This category includes families with children, who are in very different situations, in the survey. For some families, the need for more space increases as the family grows, while in others it decreases as the children move on their own.

On the other hand, based on the open answers (82 responses) in this part of the survey, the most important reasons for and targets of the desire to move were: (1) internal migration in the Helsinki metropolitan area (17 mentions/21\%); (2) the size of the apartment is too small (10 mentions/12\%); (3) out of the metropolitan area or into the countryside (7 mentions $/ 9 \%)$; (4) into the center of Helsinki for a quieter area (6 mentions $/ 7 \%)$; and (5) family reasons/desire to live closer to family members (4 mentions $/ 5 \%$ ).

\subsection{Preferred Number of Floors}

Most of the residents (43\%) surveyed preferred a 1-2-storey building to live in and as the number of floors increased, the preference rate decreased, as seen in Figure 7. Interestingly, however, more than a quarter of the respondents stated that the number of floors is not a criterion in choosing the building to be inhabited. 


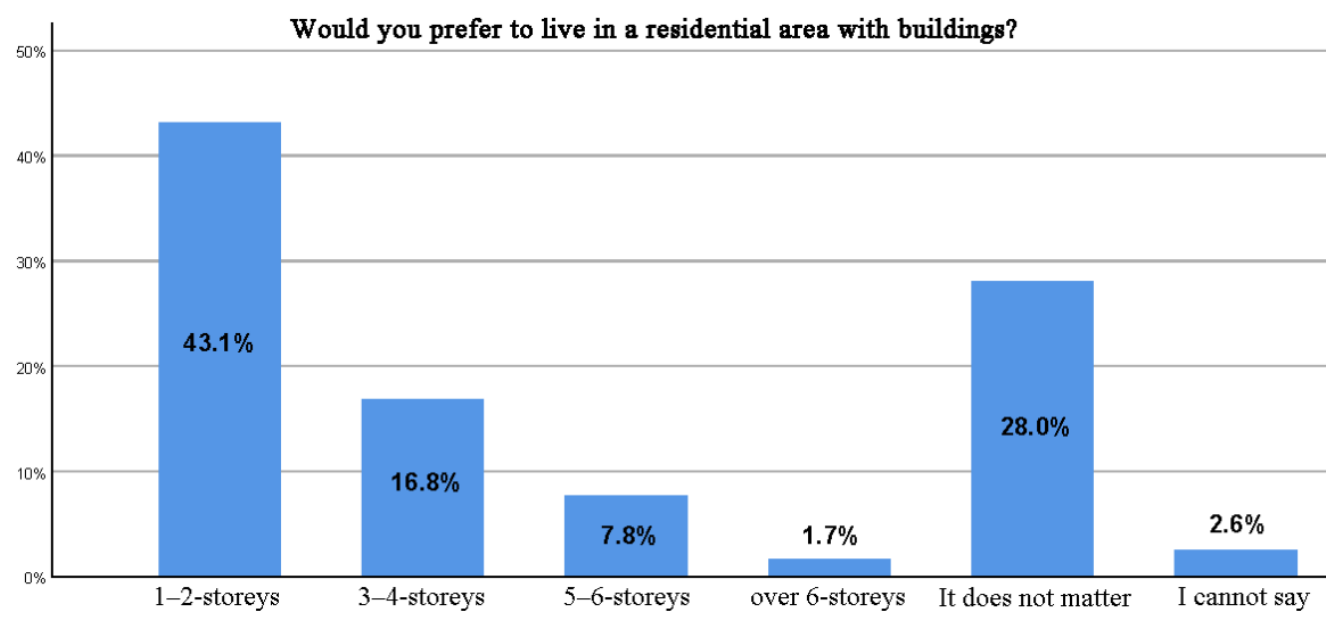

Figure 7. Preferred number of floors.

Figure 8 shows the residents' attitude towards the number of floors by building type inhabited. While those living in small houses preferred to live in buildings with 1-2-storeys by a wide margin, this rate decreased significantly among those living in apartments. This may be an indication of the influence of habits on preferences. On the other hand, while approximately one-third of the apartment residents thought that the number of floors is unimportant for the comfort of the residential area, this preference represented the minority for those living in small houses.
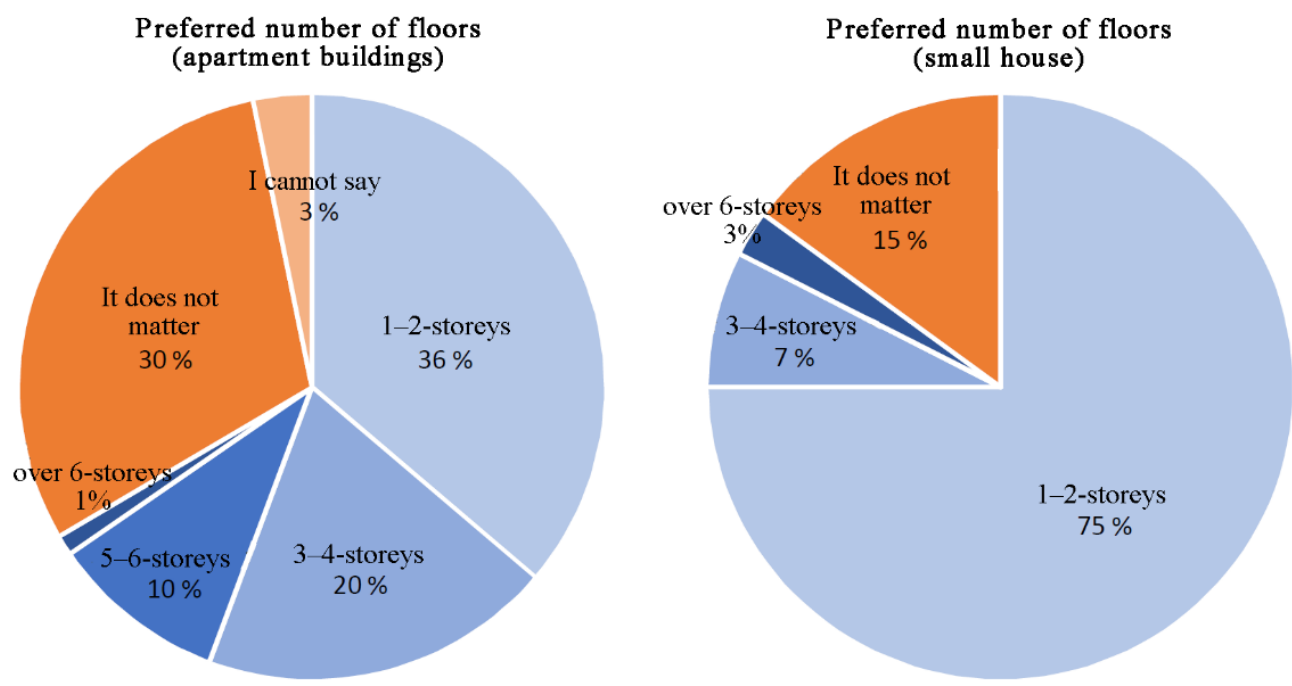

Figure 8. The effect of the residential building type on the preference of number of floors.

\subsection{Preferred Density and Location of the Building on the Plot}

As shown in Figure 9, the vast majority of the participants (84\%) preferred low-density housing, while a negligible minority supported a high-density living environment. This may be an indication that quiet and secluded suburban living was widely accepted among surveyed residents.

According to the survey result, while nearly half of the respondents $(>45 \%)$ thought that living in the center was more attractive, nearly one-third of them $(>30 \%)$ stated that it was not important where the residence was located on the plot-see Figure 10. A small part of the participants (14\%) preferred living close to the street. 


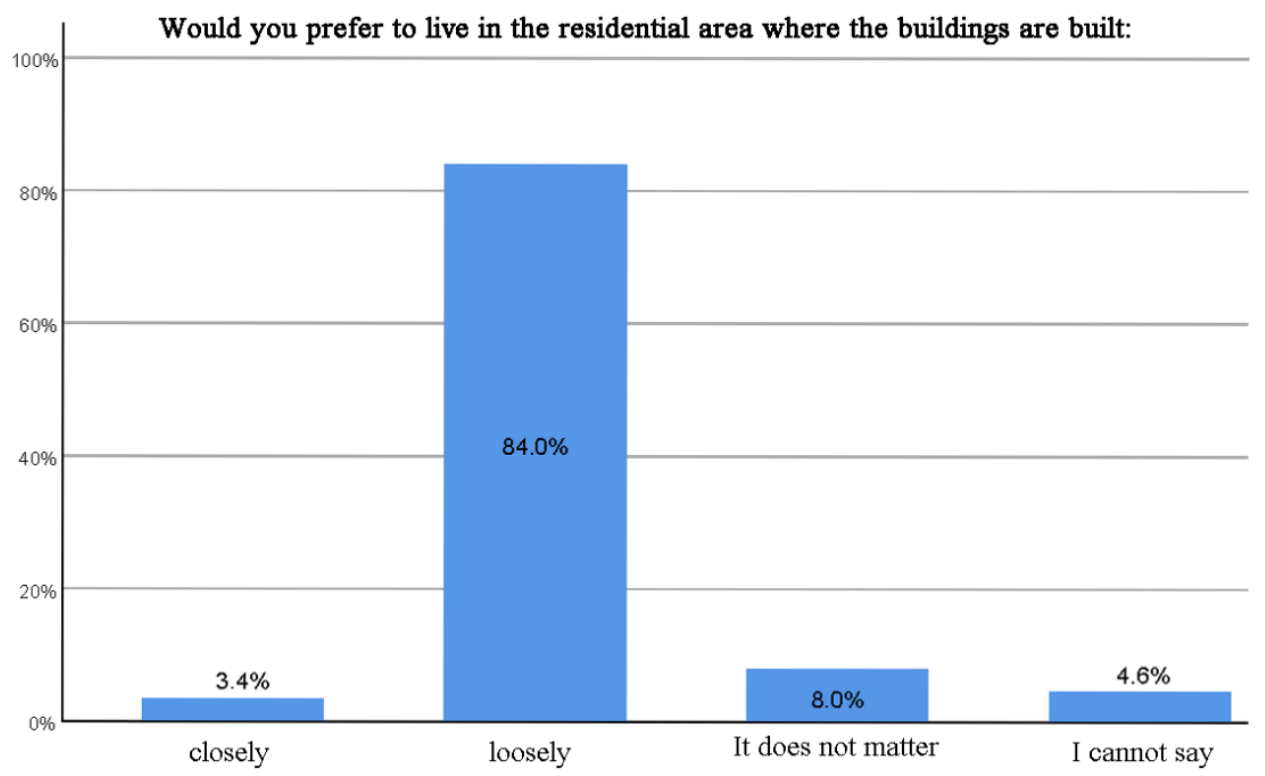

Figure 9. Preferred density.

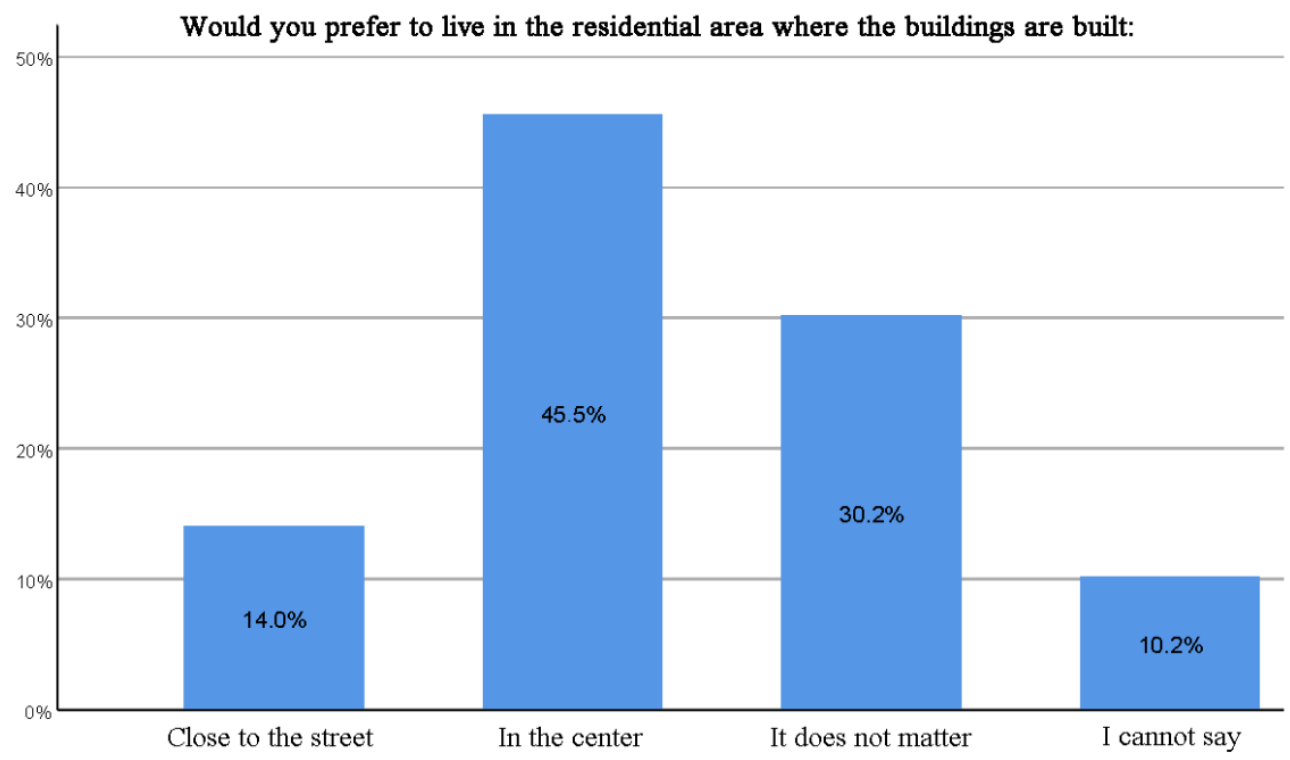

Figure 10. Preferred location of the building on the plot.

\subsection{Preferred Facade Material}

Figure 11 highlights the most popular facade materials reported by the respondents, in the following order of importance: (1) wood (44\%); (2) other (10\%); (3) brick (7\%); and (4) plastering (3\%). A quarter of participants reported that facade materials are not important to their residential satisfaction.

\subsection{Preferred Features in the Residential Environment}

Based on the open answers, the participants considered a calm environment intertwined with nature, and greenery, as important factors when choosing a residential area, regardless of the building stock. In addition, the importance of good services nearby, childfriendly areas in the immediate vicinity, the proximity of water bodies, the preservation of old woods, the quality of courtyard environment, the tranquility of the residential area, and the sense of security, were emphasized.

Moreover, according to survey respondents: (a) suburban designers should pay more attention to the development of yard areas, plantations, and park areas; (b) the yards in par- 
ticular should be comfortable, green and suitable for leisure use and playgrounds for children; (c) park walkways should be naturally designed for the shortest route; (d) investing in child-friendly development in suburban development significantly increases the attractiveness of a residential area.

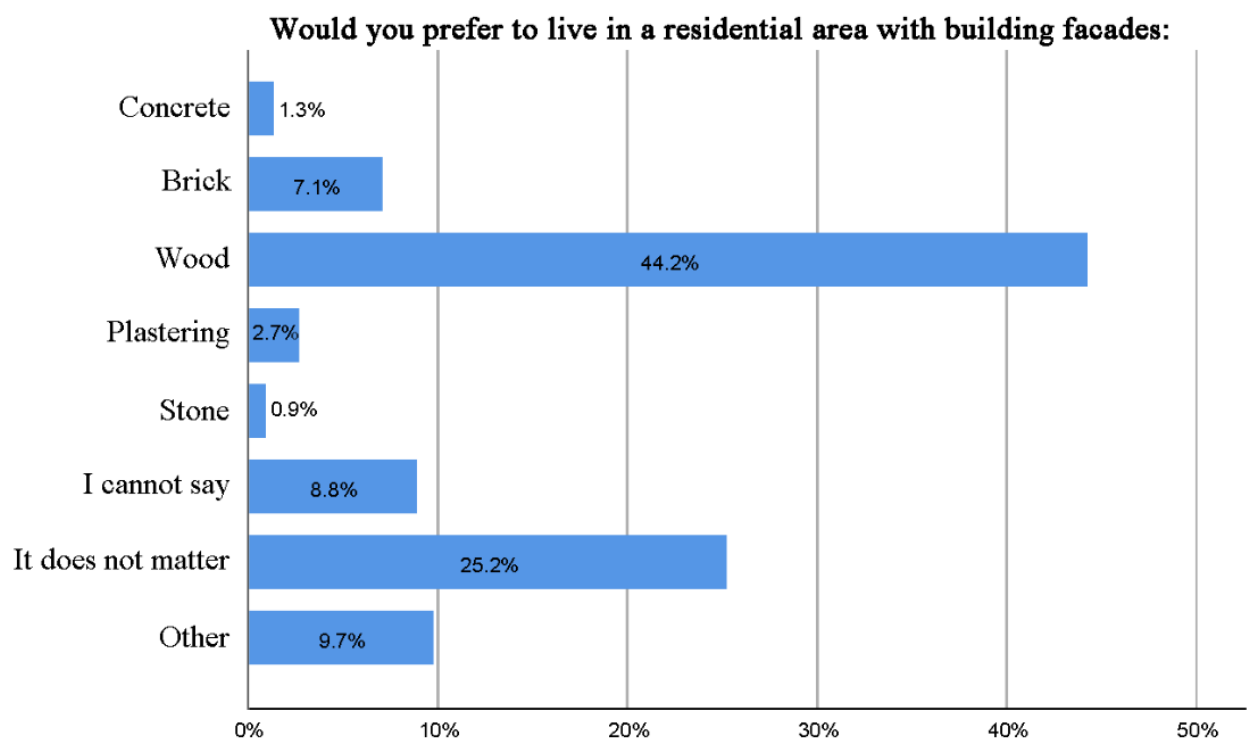

Figure 11. Preferred facade material.

\subsection{Perception of Wood as a Building Material}

Figure 12 highlights that participants' attitudes towards the use of wood in construction were generally very positive (93\%), and background variables did not significantly affect attitudes. While all the people living in a wooden building thought of it positively, $8 \%$ of the people living in a partially wooden building had a partially negative perception of it. This was because they had had bad experiences with the combination of wood and other materials.

\section{How do you feel about the use of wood in construction?}

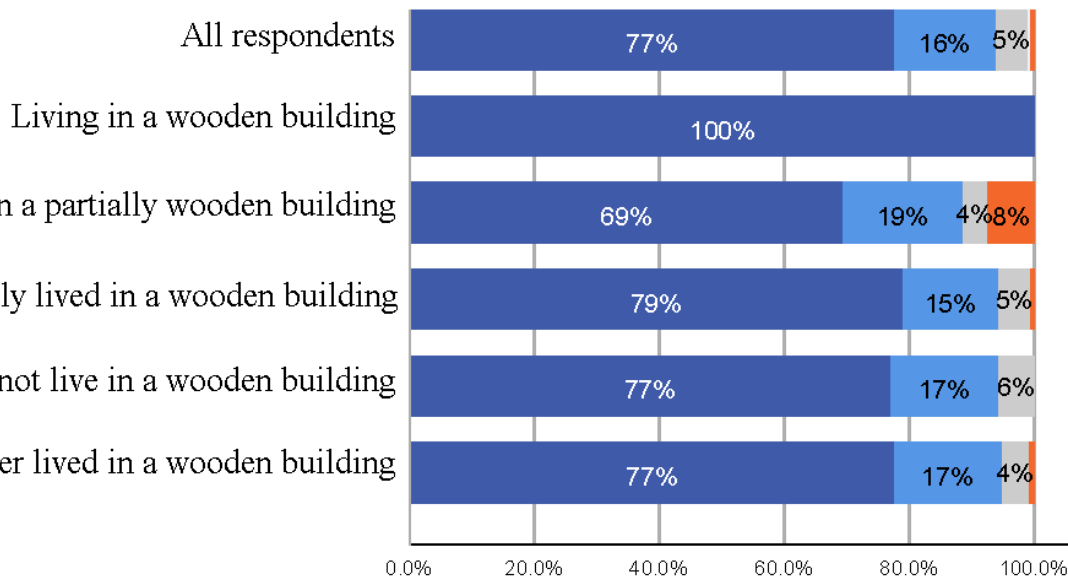

negatively partially negatively I do not know positively partially positively neutral

Figure 12. Effect of living in a wooden building on attitudes towards the use of wood.

The surveyed residents generally supported that more wooden buildings should be constructed in Finland (the total occurrence of "completely agree" and "partially agree" options, $82 \%$ ) and disagreement with this statement held a negligible minority in the 
responses $(>3 \%)$, while "neutral" had a 13\% occurrence-see Figure 13. About one-third of the respondents found non-wood materials, e.g., stone and brick, to be more suitable for buildings.

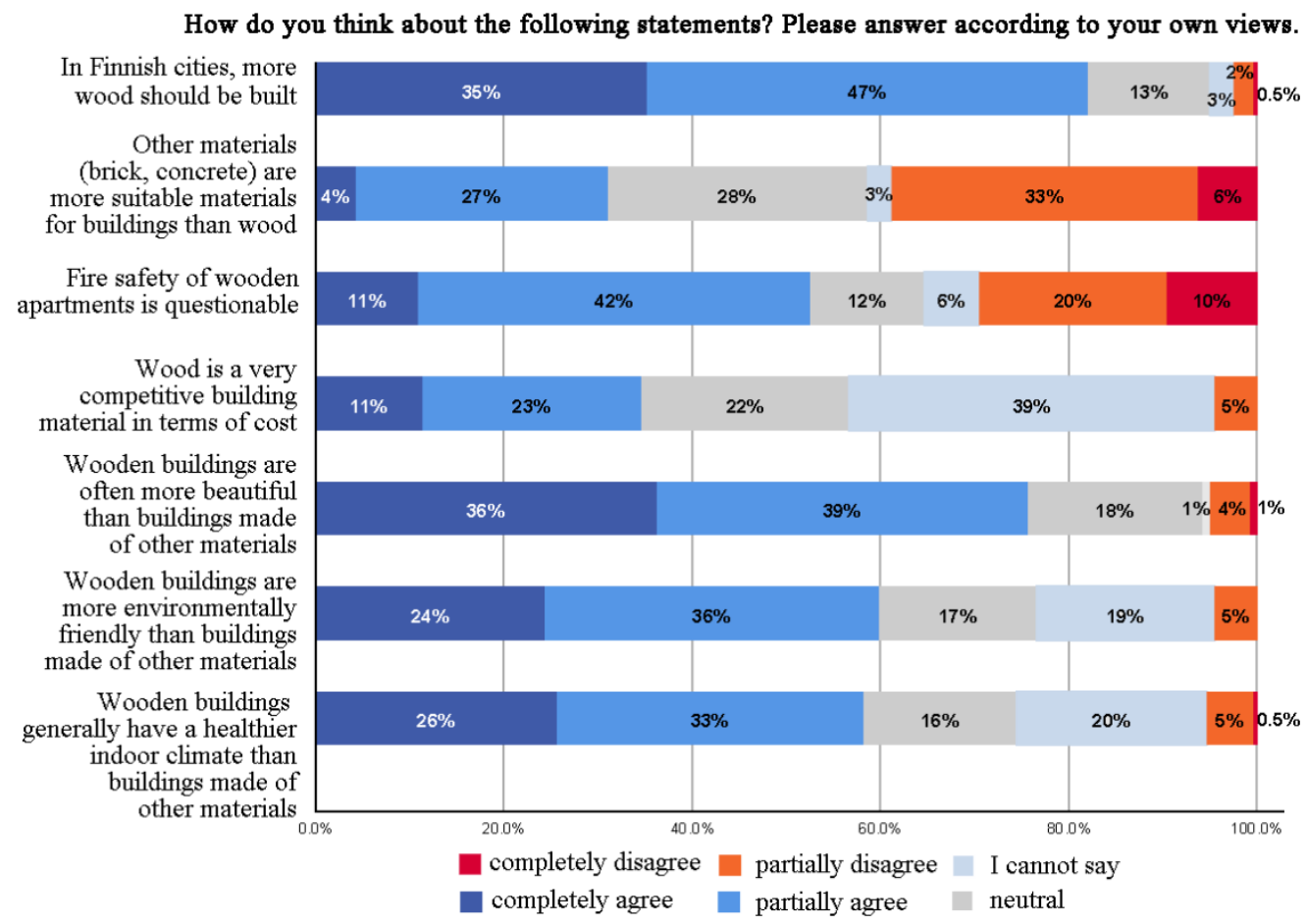

Figure 13. Perception of wood as a building material.

The issue of fire safety was considered the main weakness of wood, as more than half of the respondents at least partially agreed that this was an issue. On the other hand, regarding the cost-competitiveness of wood, the majority (61\%) were skeptical, providing "neutral" and "I can't say" options.

Residents mostly rated wooden buildings as more beautiful than buildings made of other materials (total occurrence of "completely agree" and "partially agree", 75\%). In addition, there was a dominant perception $(60 \%)$ in residents that wood is generally more environmentally friendly than other building materials, and a similar majority (59\%) considered wooden structures to have a healthier indoor climate than buildings made of non-wood materials.

\subsection{Perception of the Ecologicality of the Use of Wood}

The overwhelming majority (89\%) of the respondents rated the use of wood in construction as ecological and somewhat ecological. In addition, respondents justified their responses by highlighting the renewable and ecological nature of wood compared to other building materials, its importance in climate change issues, and its role as a carbon sink, in the free comment section.

Furthermore, based on the open answers (97 responses) on the use and ecology of wood, comments were given in the following order of frequency: (1) I like the look/beautiful material (31 mentions/30\%); (2) wood is a renewable resource/ecological (16 mentions/16\%); (3) natural/organic/warm/cozy material (13 mentions/13\%); (4) there is plenty of wood available in Finland (11 mentions /11\%); (5) traditional/domestic building material (10 mentions $/ 10 \%)$; (6) wood is a more ecological option than other materials ( 9 mentions $/ 9 \%$ ). 


\subsection{Feedback}

Participants were asked to give feedback to the developers and wooden apartment designers. Based on the open answers (110 responses), comments were given in the following order of frequency: (1) areas must not be built too full (15 mentions/14\%); (2) I support wood construction (10 mentions $/ 9 \%$ ); (3) coloring should not be gloomy (8 mentions/7\%); (4) keep up the good work with wood (7 mentions/6\%); (5) wood construction would improve the appearance of the area (6 mentions $/ 5 \%)$.

\section{Discussion}

When our results are compared with the findings of other studies, there are some similarities, such as residential satisfaction $[25,26]$, and differences, such as fire safety issues [49,50], as detailed below. It is worth noting here that Karjalainen's surveys of suburban residents of wooden apartments in Finland $[25,26,34]$ are comparable to ours since they include some of the main themes of our study, such as residents' satisfaction with their current residence, perception of housing, and perception of wood as a building material.

In terms of residential satisfaction with current residence, the surveyed participants were generally satisfied with the overall condition of their residence, including residential area, quality of the residence, and price/rental level. In addition, according to the open answers, the location, proximity to nature, comfort of the area, and the size of the apartment and the floor plan were considered among the most significant parameters affecting the current residence decisions. This resembled the findings of Karjalainen's surveys $[25,26]$ on residents' satisfaction with their current residence. In these surveys, the functionality of the apartment unit, the immediate surroundings, and the amount of furniture were reported as critical features that ensure residential satisfaction. Similarly, in a Swedish study on quality of life in wooden multi-family houses by Lindblad [51], location and the size of the apartment unit were assessed as important considerations.

Regarding willingness to move, most of the respondents stated that they do not intend to move from the area they live in. This can be associated with the above-mentioned state of residential satisfaction. On the other hand, our results regarding the preferred number of floors and density can be attributed to the findings of the study by Karjalainen [25]. In his survey, detached and one- or two-storey terraced houses were the most popular types to move into among residents. Similarly, most of the residents surveyed in this study preferred 1-2-storey buildings and low-density residences for living. Additionally, according to the survey results, the majority thought that living in the center is more attractive. This can be explained by the fact that Finnish city centers (e.g., Helsinki City) [52] are within walking distance of many socio-cultural activities and services that fulfil daily needs, such as shopping and healthcare facilities, as are many urban centers in developed countries [53].

Among the facade materials, wood was widely rated as the most preferred material by the surveyed suburban residents. Similarly, Karjalainen [26] identified residents' desire to have more timber in their apartments, such as in the facades. Our finding can also be identified in Lindblad's research [51], in which timber as a facade material was of great importance among participants. Additionally, this may be identified in the interview study conducted by Viholainen et al. [50] on Finnish households, where it was suggested to increase the use of wood on the surfaces to create attractive soundscapes.

Participants' attitudes towards the use of wood in construction were generally very positive, and background variables (e.g., to live or not to live in a wooden apartment) did not significantly affect these attitudes. Similarly, in Karjalainen's studies [25,26], the interviewees mostly welcomed wooden construction and multi-storey wooden apartment buildings. These findings may be a concrete indication of the positive perception of wood as a building material in the Finnish housing market [54-56].

In terms of preferred features in the suburban residential environment, issues regarding the immediate surroundings of the residence, such as closeness to nature, child-friendly areas in the immediate vicinity and proximity of water bodies, were considered as impor- 
tant parameters. These findings point to the important role of the immediate surroundings in residential satisfaction, which was also included in Karjalainen's research [25].

In the part of the survey on the perception of wood as a building material, while fire safety was seen as a problematic issue, its cost was not found to be competitive compared to other building materials. In this context, our finding on fire safety was similar to the findings of the study of Kylkilahti et al. on Finnish residents [57], the study of Høibø et al. on Norwegian residents [58], Gold and Rubik's study on German residents [59], and the study of Larasatie et al. on American residents [60], whose respondents were also skeptical about the technical features of wood, such as fire resistance.

Furthermore, there is no literature on resident perceptions of cost-competitiveness, but the opinions of construction professionals (e.g., architects, engineers) support our results (e.g., [61-63]). On the other hand, according to Karjalainen's recent survey [26], suburban residents often took into account technical measures (e.g., fire alarm systems) to improve fire safety, as supported by the findings of Östman et al. [49] and Viholainen et al. [50].

In the above-mentioned, while support was given to the statement that Finnish cities should be built using more wood, wood was generally considered to be more beautiful and more environmentally friendly than other materials. Moreover, wooden structures were mostly reported to have a healthier indoor climate than buildings made of non-wood materials.

On the other hand, in terms of perception of ecologicality, the vast majority emphasized the ecological aspect of the use of wood in construction. Similarly, in the study by Karjalainen [26], participants rated wooden apartment buildings as pleasant and beautiful, ecological/eco-friendly, and having a good indoor climate. Moreover, according to the findings by Lähtinen et al. [54], the Finnish residents surveyed were satisfied with the wood's health and aesthetic properties.

Finally, the feedback given by the participants to the developers and wooden apartment designers underlines their support for wooden construction. Similar feedback was given to designers and developers of multi-storey timber apartments in Karjalainen's research [34].

\section{Conclusions}

This research aimed to provide a representative analysis of Finnish suburban residents preference for a livable housing environment and its relationship to the use of wood as a building material. In doing so, this study attempted to identify the main parameters behind residential satisfaction with the current residence, willingness to move, preferred number of floors, the preferred density and location of the building on the plot, the preferred facade material, preferred features in the residential environment, perception of wood as a building material, and the perception of the ecologicality of the use of wood.

According to the result, the suburban residents surveyed were generally satisfied with the general condition of their residence, and most of them did not plan to move elsewhere. The majority supported living in 1-2-storey buildings and low-density residential environments. Most of the respondents thought that living in the center would be more attractive. The most popular facade material reported by Finnish residents was wood. In terms of the preferred features in the residential environment, excluding building stock, issues related to the immediate surroundings, such as proximity to nature, the availability of child-friendly areas, and the proximity of water bodies, were considered as important features. The attitudes of the participants towards the use of wood in construction were generally very positive, and they supported the construction of more wooden buildings in Finland. Residents generally considered wooden buildings more beautiful, more environmentally friendly/ecological, and as having a healthier indoor climate than buildings made of non-wood materials. On the other hand, fire safety and cost-competitiveness were issues of skepticism among participants.

In conclusion, this study can serve as a roadmap for interested parties, such as contractors, architects and policymakers, by revealing the preferences of suburban residents for a more livable housing environment. In this sense, sustainable solutions, including more 
wood construction, can be developed for new design approaches and renovation projects for suburbs, which have been on the agenda for a long time in Finland.

Several limitations of this study should be mentioned. While a fairly representative sample of the typical Finnish suburb district was studied in general, there may be a sample group that is more compatible with the chosen region, especially for some background variables, e.g., education level. Furthermore, to make the results more convincing for Finland's general population, much larger sample sizes with higher response rates of surveyed patricians should be studied. Additionally, the assessment of livability has inherent limitations [64], often stemming from the subjectivity of human needs and perception, which poses the greatest challenge in assessing livability.

Future research should explore more models of analysis for both urban and suburban livability, so as to provide a more accurate reference for regional planning and development. Future studies may also include other background variables (for example, residents' income level, past residence experience) to enhance and enrich insight into residents' livability preferences. In addition, comparative studies can be conducted by performing similar surveys in other Nordic countries.

Author Contributions: Conceptualization, M.K., H.E.I., L.M. and M.N.; methodology, M.K., H.E.I., L.M. and M.N.; software, H.E.I. and L.M.; formal analysis, M.K., H.E.I., L.M. and M.N.; investigation, M.K., H.E.I., L.M. and M.N.; data curation, M.K., H.E.I., L.M. and M.N.; writing—original draft preparation, H.E.I.; writing—review and editing, M.K., H.E.I., L.M. and M.N.; visualization, H.E.I. and L.M.; supervision, M.K. and M.N.; project administration, M.K. and M.N.; funding acquisition M.K., L.M. and M.N. All authors have read and agreed to the published version of the manuscript.

Funding: This research was funded by the Wood Construction Program of the Finnish Ministry of the Environment.

Institutional Review Board Statement: Not applicable.

Informed Consent Statement: Not applicable.

Data Availability Statement: Not applicable.

Conflicts of Interest: The authors declare no conflict of interest.

\section{Appendix A Questionnaire}

\section{Background Information}

1. Date of response:

2. Respondent's gender: * Female * Male

3. Respondent's age: ___ Level of education: * Primary school * High school * University * I cannot say

4. Size of respondent's household: adults, children $(<18$ y)

5. Form of ownership: ${ }^{*}$ Rental ${ }^{*}$ Owned ${ }^{*}$ Right-of-occupancy ${ }^{*}$ Elsewhere?

6. How long have you lived in your current residence: ___ years___ months.

7. What kind of building do you live in? * Apartment * Semi-detached house * Detached house * Elsewhere? In the survey, wooden structure refers to a structure whose external appearance is mostly wooden, that is, its facade is wooden.

8. Is your residential building a wooden building? * Yes * $\mathrm{No}^{*} \mathrm{I}$ cannot say

9. Have you lived in a wooden building before? ${ }^{*} \mathrm{Yes}^{*} \mathrm{No}^{*} \mathrm{I}$ cannot say

\section{Own residential area}

The survey refers to the residential area of Pukinmäki and especially the immediate surroundings of your own home.

10. How do you feel about? Very satisfied/Satisfied/Neutral/Dissatisfied/Very dissatisfied/I cannot say
(a) your area of residence
(b) quality of your residence 
(c) price/rent level of your residence

11. What was the most important influence on the choice of your current place of residence?

12. Are you planning to move from this residential area?

(a) * Yes * No* I cannot say

(b) If you answered that you are planning to move: Why would you want to move? And where?

\section{Wood in the Construction}

13. What do you think about the use of wood in construction?

* Positive * Partially positive * Neutral * Partially negative * Negative * I cannot say

14. Do you think about the use of wood in construction?

* Ecological * Somewhat ecological * Neither ecological nor non-ecological

* Somewhat non-ecological * Non-ecological * I cannot say

15. If you wish, give reasons for your answers to questions 14 and 15.

16. What do you think about the following? Completely agree/Partially agree/Neutral/ Partially disagree/Disagree/I cannot say

\section{(a) In Finnish cities}

more wood should be built

(b) Other materials

(brick, concrete) are more suitable materials for buildings than wood

(c) The fire safety of wooden

apartment is questionable

(d) Wood is a very competitive

building material in terms of cost

(e) Wooden buildings are often

more beautiful than buildings made of other materials

(f) Wooden buildings are generally

more environmentally friendly than buildings made of other materials

(g) Wooden buildings generally have

a healthier indoor climate than buildings made of other materials

\section{Residential Environment}

17. Would you rather live in a residential area with buildings:

* 1-2-storey * 3-4-storey * 5-6-storey * more than 6-storey

* It does not matter * I cannot say

18. Would you prefer to live in a residential area with building facades:

* Concrete * Stone * Brick ${ }^{*}$ Steel ${ }^{*}$ Wood

* Ceramic tile* Plastering * I cannot say

* Facade materials do not matter ${ }^{*}$ Elsewhere?

19. Would you prefer to live in a residential area where the buildings are located on a plot of land:

* Close to the street * In the center * It does not matter * I cannot say

20. Would you prefer to live in the residential area where the buildings are built:

* Closely * Loosely * It does not matter * I cannot say

21. Which of the following factors is more important on the facade of the building for a pleasant living environment?

In this regard, facade architecture essentially means the appearance of the building, the layout of windows and balconies, and the details of the facade. 
* Facade material or facade coloring

* Facade material or facade architecture

* Facade coloring or facade architecture

Other comments and feedback for timber apartment building developers and designers:

\section{References}

1. Tuominen, P. Historical and Spatial Layers of Cultural Intimacy: Urban Transformation of a Stigmatised Suburban Estate on the Periphery of Helsinki. Soc. Incl. 2020, 8, 34-43. [CrossRef]

2. Simson, R.; Fadejev, J.; Kurnitski, J.; Kesti, J.; Lautso, P. Assessment of Retrofit Measures for Industrial Halls: Energy Efficiency and Renovation Budget Estimation. Energy Procedia 2016, 96, 124-133. [CrossRef]

3. Moll, V.; Kuusi, H. From city streets to suburban woodlands: The urban planning debate on children's needs, and childhood reminiscences, of 1940s-1970s Helsinki. Urban Hist. 2019, 48, 125-142. [CrossRef]

4. Hankonen, J. Lähiöt ja Tehokkuuden Yhteiskunta: Suunnittelujärjestelmän Läpimurto Suomalaisten Asuntoalueiden Rakentumisessa 1960-Luvulla; Gaudeamus: Otatieto, Finland, 1994.

5. The New Arrival of the Suburbs, YIT. Available online: https://www.yit.fi/en/in-focus/future-of-suburbs (accessed on 24 October 2021).

6. The Finnish Timber of Council (Puuinfo). Available online: https://puuinfo.fi/?lang=enç (accessed on 24 October 2021).

7. The Bright Future of Suburbs, YIT. Available online: https://news.cision.com/yit-oyj/r/the-bright-future-of-suburbs,c3023589 (accessed on 24 October 2021).

8. Musterd, S.; van Kempen, R. Large-scale Housing Estates in European Cities: Opinions of Residents on Recent Developments. RESTATE Report 4k; Urban and Regional Research Centre: Utrecht, The Netherlands, 2005.

9. Rowlands, R.; Musterd, S.; van Kempen, R. (Eds.) Mass Housing in Europe: Multiple Faces of Development, Change and Response; Palgrave Macmillan: London, UK, 2009.

10. Wassenberg, F. Large Housing Estates: Ideas, Rise, Fall and Recovery. The Bijlmermeer and Beyond. Sustainable Urban Areas; Delft University Press: Delft, The Netherlands, 2013.

11. Saarikangas, K. Merkityksellinen Tila: Lähiöasuminen Arkkitehtuurin, Asukkaiden, Aenneen ja Nykyisen Nohtaamisena. In Eletty ja Muistettu Tila. Historiallinen Arkisto, 115; Syrjämaa, T., Tunturi, J., Eds.; Suomalaisen Kirjallisuuden Seura: Helsinki, Finland, 2002; pp. 48-75.

12. Saarikangas, K. Asukkaat ja Maisema Liikkeessä: Lähiörakentaminen ja asumisen mullistus 1960-luvulla. In Värikkäämpi, Iloisempi, Hienostuneempi: Näkökulmia 1960-Luvun Arkkitehtuuriin; Lahti, J., Rauske, E., Eds.; Arkkitehtuurimuseo: Helsinki, Finland, 2016; pp. 67-93.

13. Costly City Homes, Crumbling Country Houses-Finland's Top 5 Housing Problems. Available online: https://yle.fi/ uutiset/osasto/news/costly_city_homes_crumbling_country_houses_finlands_top_5_housing_problems/10447688 (accessed on 24 October 2021).

14. Huttunen, H.; Blomqvist, E.; Ellilä, E.; Hasu, E.; Perämäki, E.; Tervo, A.; Verma, I.; Ullrich, T.; Utriainen, J. The Finnish Townhouse as a Home. Starting Points and Interpretations. Habitat Components-Townhouse. Final Report. Aalto University Publication Series CROSSOVER 8/2017. Helsinki, Finland, 2017. Available online: https:/ / aaltodoc.aalto.fi/bitstream/handle/123456789/30 185/isbn9789526071220.pdf?sequence=1\&isAllowed=y (accessed on 24 October 2021).

15. There is a Need for Diverse, Market-Driven Housing Construction and for State-Subsidised, Affordable Housing Production to Supplement it, Housing Policy, Finnish Government. Available online: https:/ /valtioneuvosto.fi/en/marin/governmentprogramme/housing-policy (accessed on 24 October 2021).

16. Wood Construction Is Being Promoted in Finland, Ministry of Agriculture and Forestry of Finland. Available online: https: $/ / \mathrm{mmm}$.fi/en/en/forests/use-of-wood/wood-construction (accessed on 24 October 2021).

17. Suburban Regeneration, The City of Helsinki. Available online: https://www.uuttahelsinkia.fi/en/sustainable-urbandevelopment/suburban-regeneration/suburb-programme (accessed on 24 October 2021).

18. Toppinen, A.; Autio, M.; Sauru, M.; Berghäll, S. Sustainability-driven new business models in wood construction towards 2030. In Towards a Sustainable Bioeconomy: Principles, Challenges and Perspectives; Leal-Filho, W., Pociovalisteanu, D.M., Borges-de-Brito, P.R., Borges-de-Lima, I., Eds.; Springer: Cham, Switzerland, 2018; pp. 499-516.

19. Carù, A.; Cova, B. Consuming Experience; Routledge: London, UK, 2007.

20. Geels, F.W. Technological transitions as evolutionary configuration processes: A multi-level perspective and a case-study. Res. Policy 2002, 31, 1257-1274. [CrossRef]

21. McMeekin, A.; Southerton, D. Sustainability transitions and final consumption: Practices and socio-technical systems. Technol. Anal. Strat. Manag. 2012, 24, 345-361. [CrossRef]

22. Gram-Hanssen, K. Retrofitting owner-occupied housing: Remember the people. Build. Res. Inf. 2014, 42, 393-397. [CrossRef]

23. Geels, F.W.; McMeekin, A.; Mylan, J.; Southerton, D. A critical appraisal of Sustainable Consumption and Production research: The reformist, revolutionary and reconfiguration positions. Glob. Environ. Chang. 2015, 34, 1-12. [CrossRef]

24. Stjernberg, M. Concrete Suburbia: Suburban Housing Estates and Socio-Spatial Differentiation in Finland. Ph.D. Thesis, Department of Geosciences and Geography A 77, Faculty of Science, University of Helsinki, Helsinki, Finland, 2019. 
25. Karjalainen, M. The Finnish Multi-Story Timber Apartment Building as a Pioneer in the Development of Timber Construction; University of Oulu: Oulu, Finland, 2002.

26. Karjalainen, M. Timber Apartment Building Resident and Developer Survey 2017; Final Report; Finland's Ministry of the Environment: Helsinki, Finland, 2017.

27. Kovacs-Györi, A. Cabrera-Barona, P. Assessing Urban Livability through Residential Preference-An International Survey. Data 2019, 4, 134. [CrossRef]

28. Van Kamp, I.; Leidelmeijer, K.; Marsman, G.; de Hollander, A. Urban environmental quality and human well-being: Towards a conceptual framework and demarcation of concepts; a literature study. Landsc. Urban Plan. 2003, 65, 5-18. [CrossRef]

29. Blečić, I.; Bibo Cecchini, A.; Talu, V. The Capability Approach in Urban Quality of Life and Urban Policies: Towards a Conceptual Framework. In City Project and Public Space; Springer: Dordrecht, The Netherlands, 2013; ISBN 9789400760370.

30. Pacione, M. URBAN LIVEABILITY: A REVIEW. Urban Geogr. 1990, 11, 1-30. [CrossRef]

31. Kovacs-Györi, A.; Cabrera-Barona, P.; Resch, B.; Mehaffy, M.; Blaschke, T. Assessing and Representing Livability through the Analysis of Residential Preference. Sustainability 2019, 11, 4934. [CrossRef]

32. Young, E.; Hermanson, V. Livability Literature Review: A Synthesis of Current Practice; TRID: Washington, DC, USA, 2012.

33. Booi, H.; Boterman, W.R. Changing patterns in residential preferences for urban or suburban living of city dwellers. Neth. J. Hous. Environ. Res. 2019, 35, 93-123. [CrossRef]

34. Karjalainen, M.; Ilgin, H. The Change over Time in Finnish Residents' Attitudes towards Multi-Story Timber Apartment Buildings. Sustainability 2021, 13, 5501. [CrossRef]

35. Borges, L.A.; Nilsson, K.; Tunström, M.; Dis, A.T.; Perjo, L.; Berlina, A.; Costa, S.O.; Fredricsson, C.; Grunfelder, J.; Johnsen, I.; et al. White Paper on Nordic Sustainable Cities Developed by Nordregio, Nordregio Magazine. 2017. Available online: http: //www.nordregio.se/nordicsustainablecities (accessed on 24 October 2021).

36. Sustainable Development Goals (SDG), the United Nations. Department of Economic and Social Affairs Sustainable Development. Available online: https://www.un.org/sustainabledevelopment/news/communications-material/ (accessed on 24 October 2021).

37. Smart City, VTT Technical Research Centre of Finland Ltd. Available online: https://www.vttresearch.com/en/topics/smart-city (accessed on 24 October 2021).

38. Litman, T. Where We Want to be Home Location Preferences and Their Implications for Smart Growth, Victoria Transport Policy Institute, The Congress for New Urbanism Transportation Summit 4 November 2009, Portland, Oregon. Available online: https:/ / www.vtpi.org/sgcp.pdf (accessed on 24 October 2021).

39. Jansen, S.J. Urban, suburban or rural? Understanding preferences for the residential environment. J. Urban. Int. Res. Placemaking Urban Sustain. 2020, 13, 213-235. [CrossRef]

40. Zhan, D.; Kwan, M.-P.; Zhang, W.; Fan, J.; Yu, J.; Dang, Y. Assessment and determinants of satisfaction with urban livability in China. Cities 2018, 79, 92-101. [CrossRef]

41. Petkar, A.S.; Macwan, J.E.M. Criteria Analysis of Residential Location Preferences: An Urban Dwellers' Perspective. Int. J. Urban Civ. Eng. 2018, 12, 49-55.

42. Allen, N.; Haarhoff, E.; Beattie, L. Enhancing liveability through urban intensification: The idea and role of neighbourhood. Cogent Soc. Sci. 2018, 4, 1442117. [CrossRef]

43. Brookfield, K. Residents' preferences for walkable neighbourhoods. J. Urban Des. 2016, 22, 44-58. [CrossRef]

44. Tapsuwan, S.; Mathot, C.; Walker, I.; Barnett, G. Preferences for sustainable, liveable and resilient neighbourhoods and homes: A case of Canberra, Australia. Sustain. Cities Soc. 2018, 37, 133-145. [CrossRef]

45. Sinniah, G.K.; Shah, M.Z.; Vigar, G.; Aditjandra, P.T. Residential Location Preferences: New Perspective. Transp. Res. Procedia 2016, 17, 369-383. [CrossRef]

46. Petrić, J.; Bajic, T. Variability of Suburban Preference in a Post-socialist Belgrade. In Proceedings of the 3rd Human and Social Sciences at the Common Conference, online, 5-9 October 2015; pp. 134-139. Available online: www.hassacc.com (accessed on 24 October 2021). [CrossRef]

47. Report on the Survey on the Provision of Livable Housing Design: The Costs and Benefits to Australian Society, RCD.9999.0439.0001, Australian Network for Housing Design. 2018. Available online: https:/ /agedcare.royalcommission.gov. au/system/ files/2020-08/RCD.9999.0439.0001.pdf (accessed on 24 October 2021).

48. Lukuman, M. Sustainable Livable Housing Assessment Model for Traditional Urban Areas in Nigeria. Ph.D. Thesis, Faculty of Built Environment and Surveying, Universiti Teknologi, Johor Bahru, Malaysia, 2018.

49. Östman, B.; Brandon, D.; Frantzich, H. Fire safety engineering in timber buildings. Fire Saf. J. 2017, 91, 11-20. [CrossRef]

50. Viholainen, N.; Kylkilahti, E.; Autio, M.; Toppinen, A. A home made of wood: Consumer experiences of wooden building materials. Int. J. Consum. Stud. 2020, 44, 542-551. [CrossRef]

51. Lindblad, F. Living quality in wooden multi-family houses. PRO LIGNO 2019, 15, 434-441.

52. City of Helsinki. Available online: https://www.hel.fi/helsinki/en/ (accessed on 24 October 2021).

53. Ali, M.M.; Al-Kodmany, K. Tall Buildings and Urban Habitat of the 21st Century: A Global Perspective. Buildings 2012, 2, 384-423. [CrossRef]

54. Lähtinen, K.; Harju, C.; Toppinen, A. Consumers' perceptions on the properties of wood affecting their willingness to live in and prejudices against houses made of timber. Wood Mater. Sci. Eng. 2019, 14, 325-331. [CrossRef] 
55. Toppinen, A.; Röhr, A.; Pätäri, S.; Lähtinen, K.; Toivonen, R. The future of wooden multistory construction in the forest bio-economy-A Delphi study from Finland and Sweden. J. For. Econ. 2018, 31, 3-10.

56. Häyrinen, L.; Toppinen, A.; Toivonen, R. Finnish young adults' perceptions of the health, well-being and sustainability of wooden interior materials. Scand. J. For. Res. 2020, 35, 394-402. [CrossRef]

57. Kylkilahti, E.; Berghäll, S.; Autio, M.; Nurminen, J.; Toivonen, R.; Lähtinen, K.; Vihemäki, H.; Franzini, F.; Toppinen, A. A consumer-driven bioeconomy in housing? Combining consumption style with students' perceptions of the use of wood in multi-story buildings. Ambio 2020, 49, 1943-1957. [CrossRef] [PubMed]

58. Høibø, O.; Hansen, E.; Nybakk, E.; Nygaard, M. Preferences for urban building materials: Does building culture background matter? Forests 2018, 9, 504. [CrossRef]

59. Gold, S.; Rubik, F. Consumer attitudes towards timber as a construction material and towards timber frame houses-Selected findings of a representative survey among the German population. J. Clean. Prod. 2009, 17, 303-309. [CrossRef]

60. Larasatie, P.; Guerrero, J.E.; Conroy, K.; Hall, T.E.; Hansen, E.; Needham, M.D. What Does the Public Believe about Tall Wood Buildings? An Exploratory Study in the US Pacific Northwest. J. For. 2018, 116, 429-436. [CrossRef]

61. Mallo, M.F.L.; Espinoza, O. Awareness, perceptions and willingness to adopt Cross-Laminated Timber by the architecture community in the United States. J. Clean. Prod. 2015, 94, 198-210. [CrossRef]

62. Xia, B.; O’Neill, T.; Zuo, J.; Skitmore, M.; Chen, Q.; Skitmore, R. Perceived obstacles to multi-storey timber-frame construction: An Australian study. Arch. Sci. Rev. 2014, 57, 169-176. [CrossRef]

63. Bayne, K.; Taylor, S. Attitudes to the Use of Wood as a Structural Material in Non-Residential Building Applications: Opportunities for Growth; Australian Government, Forest and Wood Products Research and Development Corporation: Melbourne, Australia, 2006.

64. Kovacs-Györi, A. GIS-based Livability Assessment: A Practical Tool, a Promising Solution? In Proceedings of the 5th International Conference on Geographical Information Systems Theory, Applications and Management (GISTAM 2019), Heraklion, Crete, Greece, 3-5 May 2019; pp. 289-296. [CrossRef] 